\title{
Comentários ao diálogo Parmênides de Platão
}

\author{
Comments on Plato's "Parmenides"
}

\author{
Miguel Spinelli
}

Resumo: Este estudo se ocupa com algumas questões do prólogo do Parmênides, que, em geral, passam desapercebidas, mas são importantes para a compreensão da arquitetônica do diálogo. Haverá de ter, por exemplo, algum significado o fato de Platão trazer para dentro do Diálogo, Céfalo de Clazômenas (da Jônia), que veio para Atenas encontrar Antífon e ouvir dele um relato de Pitodoros sobre o que Parmênides e Zenão, vindos de Eleia (da Magna Grécia), confabularam com Sócrates em Atenas. Clazômenas é a terra de Anaxágoras, daquele que, a convite de Péricles, fundou em Atenas uma escola filosófica. Do debate que ocorreu entre Parmênides, Zenão e Sócrates, na casa de Pitodoros, foi Pitodoros, quem, por primeiro, registrou de memória; depois ele pasșou a Antífon (irmão de Platão por parte de mãe), e, Antîfon, passou a Céfalo, que, enfim, veio a ser, e não o irmão de Platão, o relator do Diálogo. Há, pois, um fluxo de personagens e de regiões que compõem o Diálogo. Há ainda algo inusitado: Zenão, perante Sócrates e seus companheiros, na casa de Pitodoros, fez uma leitura de seus "escritos", dos quais, no final, Sócrates pediu a Zenão que relesse apenas "o primeiro argumento": o do paradoxo do Um e do Múltiplo, tema sobre o qual incidiram o debate e a construção do Diálogo. Este estudo cumpre três etapas: comenta o introito, esboça a tratativa do Um e do Múltiplo e ensaia algumas possibilidades de leitura e de interpretação do Parmênides.

Palavras-chave: Platão; Parmênides; Prólogo

Abstract: This paper deals with some questions at Parmenides' prologue that generally go unnoticed, despite their significance to understand the architecture of the Dialogue. There must be some meaning, for example, in the fact of Plato having brought into the Dialogue Cephalus of Clazomenae (in Ionia), who came to Athens to see Antiphon and hear from him Pythodorus' report on what Parmenides and Zeno, both coming from Eleia (in Magna Greece), talked with Socrates in Athens. Clazomenae is the land of Anaxagoras, who, invitated by Pericles, founded a philosophical school in Athens. The debate between Parmenides, Zeno, and Socrates that took place at Pythodorus' house was, for the first time, written by heart by Pythodorus himself, and then passed on to Antiphon (Plato's brother on his mother's side), who, by his turn, transmitted the report to Cephalus who ended up being the reporter of the Dialogue, in place of Plato's brother. Therefore, a flow of characters and regions makes up the Dialogue, There still is something unusual: Zeno, before Socrates and his companions at Pythodorus' house, read his "writings", of which, in the end, Socrates asked Zeno to re-read only "the first argument": that one about the One and Many paradox, which is the theme of the debate and the construction of the Dialogue. This paper develops three stages: it comments the prologue of the Dialogue, outlines the treatment of the One and Many problem, and presents some possibilities of reading and interpreting the Parmenides.

Keywords: Plato; Parmenides; Prologue

\section{Comentários ao prólogo do diálogo}

1.1 O diálogo o Parmênides se introduz dizendo que um tal de Céfalo, residente (oíkothen) na cidade de Clazômenas, veio a Atenas com o objetivo específico de acompanhar

\footnotetext{
I Professor de Filosofia na Universidade Federal de Santa Maria, Santa Maria, RS. E-mail: migspinelli@gmail.com ORCID:
} https://orcid.org/0000-0002-4087-5579 
um grupo de compatriotas (politaí) amantes da filosofia (philósophoi). Este Céfalo ${ }^{1}$ ao qual o diálogo se refere haveria, por certo, de ser um daqueles sofistas gregos que perambulavam pela Grécia a fim de angariar o próprio sustento: quer vendendo seu próprio saber (recolhido em livros ou diretamente da confabulação com os sábios), quer acompanhando os que excursionavam ("filósofos" ou interessados pela filosofia) em busca de saber. O Céfalo referido pelo diálogo se enquadra na segunda condição: na do acompanhante de um excurso pelo saber. $\mathrm{O}$ que o qualificou para isso decorre certamente do fato de ele já ter estado em Atenas numa outra ocasião, que não necessariamente aquela em que Parmênides e Zenão por lá estiveram, e, além disso, por conhecer Antífon.

O diálogo se inicia com a seguinte assertiva, dadas como palavras de Céfalo: "Estando em Atenas, vindos de Clazômenas, onde residimos, encontramos na Ágora Adimanto e Gláucon" (Prm. 126a)². Esse evento se dá bem depois da vinda a Atenas de Zenão e Parmênides, e também alguns anos depois da morte de Sócrates e de Pitodoros. Céfalo ciceroneava seus compatriotas em busca de Antífon (irmão de Platão por parte de mãe), que, "quando ainda jovem, se ocupou em decorar" o teor das conversações havidas na casa de Pitodoros. Foi de tanto ouvir Pitodoros - fato que permite inferir uma continua preleção pública do teor da referida conversação entre Parmênides, Sócrates e Zenão - que Antífon findou por saber de cor, guardar de memória o conteúdo da conversação.

Quanto a essa chegada de Céfalo em Atenas, ela merece destaque e algumas considerações: a) Céfalo vem de Clazômenas, de uma importante cidade da Jônia, terra de Anaxágoras, justo daquele que Péricles trouxe à Atenas (na Ática) sob o propósito de erigir e fazer ali prosperar uma escola filosófica; b) Céfalo com seus compatriotas se dirige à Ágora, ou seja, justo ao centro de maior efervescência humana, política e econômica do cotidiano de Atenas, e lá encontra, não um, mas dois irmãos de Platão, Adimanto e Gláucon; c) Céfalo, como já referido, viera com os companheiros ouvir de Antífon, ou seja, de outro irmão Platão, o relato do encontro entre Sócrates, Parmênides e Zenão ocorrido na casa de Pitodoros.

O diálogo, portanto, se inicia pondo implicitamente em evidência alguns dados muito importantes: a) evidencia, por exemplo, o recinto familiar de Platão: afinal, vieram ouvir um meio-irmão de Platão e encontraram na Àgora os outros dois irmãos, Adimanto e Gláucon, e mais, foram eles que levaram Céfalo e os "filósofos" de Clazômenas até à casa de Antífon; b) além do recinto familiar de Platão é de algum modo evidenciado o da Academia: afinal, Adimanto e Gláucon são dois importantes interlocutores da dialógica platônica ${ }^{4}$; c) além da Academia, fica também implicitamente evidenciada a Escola de Anaxágoras: Céfalo, afinal, com seus companheiros "filósofos" vem de Clazômenas (na Jônia), terra do filósofo Anaxágoras, daquele que veio a ser o arquiteto e mentor da primeira escola filosófica em Atenas; d) uma vez que implicitamente se põe em evidência a Escola de Anaxágoras, não há como não se pensar na linhagem filosófica construída com a "escola", quer por Anaxágoras

\footnotetext{
${ }^{1}$ Não é o Céfalo de Siracusa, pai de Lísias que vivia no Pireo (Rep. 327 a - 331 c); Céfalo de Siracusa era um comerciante de Armas, e veio residir no Pireo a convite, e sob a proteção, de Péricles.

${ }^{2}$ Quando não indicarmos o tradutor, é porque a tradução é de nossa responsabilidade.

3 Platão e seus dois irmãos, Adimanto e Gláucon, eram filhos de Áriston com Perictione. Sua mãe, Perictione, após a morte de Áriston, esposou Pirilampo, um aristocrata e político ateniense, com o qual teve Antífon (Górgias, 481 d-e). Platão também teve uma irmã, Potone, mãe de Espeusipo, sucessor de Platão na direção da Academia.

4 BOLZANI FILHO, Glauco, o guardião do lógos, p.11-32; MOTTA, Gláucon, Adimanto e a necessidade da filosofia, p. 87-113.
} 
quer por Arquelau; e) dá-se que Arquelau é pela tradição considerado mestre de Sócrates ${ }^{5}$, deste que, por sua vez, além de mestre de Platão, veio a ser o principal personagem da dialógica com a qual Platão edificou o seu próprio projeto e legado filosófico.

Diz o Diálogo que não era a primeira vez que Céfalo vinha a Atenas. Pelo que consta no introito, ele por lá estivera uma outra ocasião quando ainda menino (paîs), ou seja, bem jovem, de modo que naquela ocasião deve ter ido acompanhado ou de algum mestre ou de algum familiar. Destacamos esse fato em razão de que o Diálogo assegura que Céfalo, apesar de ainda menino (paîs), manteve contado, naquela passagem por Atenas, com os referidos irmãos de Platão: Adimanto, Gláucon e Antífon. Aqui se impõe, evidentemente, a pergunta: e com Platão, Céfalo não teve contato? Dado que Céfalo não era de modo algum estranho aos familiares de Platão, por suposto, também haveria de ser conhecido do próprio Platão!

Quanto à primeira viagem de Céfalo a Atenas em relação à segunda, ela vem expressa no Diálogo em termos de que "faz muito tempo", mas, tudo indica que não haveria de ser tanto tempo assim. Não deveria em vista de que Céfalo, uma vez em Atenas, e circulando pelo Mercado, reconhece e é reconhecido pelos dois irmãos de Platão - por Adimanto e Gláucon - que se encontravam lá no Mercado. Depois, quando levado a Antífon, também imediatamente o reconhece. Daí que, por esse reconhecimento, fica logo evidenciado que o visage do menino Céfalo não mudara tanto assim, e permite, inclusive, inferir que ele, na primeira viagem, não haveria de ser assim tão menino, mas por certo um jovem adolescente com traços fisionômicos já bem definidos.

Em tudo isso há um fato inusitado, sobretudo, curioso, que pede por algumas considerações. O fato é este: Céfalo veio de Clazômenas com seus conterrâneos amantes da Filosofia não para ouvir Platão, e sim para ouvir a versão de Antífon, ou seja, do irmão mais novo de Platão a respeito do relato do encontro de Sócrates com Parmênides e Zenão na casa de Pitodoros. Redunda igualmente inusitado o fato de que o diálogo o Parmênides não é, na verdade, um registro que corresponderia aos escritos de Zenão lidos na casa de Pitodoros, e sim um registo do debate memorizado por Antífon, irmão de Platão, a partir de Pitodoros, e que, enfim, foi grafado por Platão como sendo um relato do próprio Céfalo que conta, de memória, o que ouviu de Antífon, a partir de Pitodoros. A questão é: por que toda essa cênica, tendo em vista que Platão poderia simplesmente ter grafado o diálogo ouvindo apenas o seu irmão, ou, até mesmo, pedido para ele redigir (colocar por escrito) o que tinha guardado na memória!

Outro fato inusitado pode ser observado a partir da seguinte assertiva presente no Parmênides: "Estas palavras (assegura o Diálogo) foram para nós dita por Antífon a partir de Pitodoros" (Prm. 136 e). Ora, este para nós faz uma referência direta a Céfalo, mas, mesmo assim, permite questionar: será que não se aplicaria indiretamente também a Platão? É de supor que sim, porque, caso não se aplicasse, resultaria então de todo inusitado o fato de que não foi diretamente de Antífon, ou seja, de seu irmão, que Platão concebeu o Pamênides, mas, indiretamente, sob a mediação de um relato de Céfalo de Cazômenas, que, enfim, veio até Atenas primordialmente ciceronear seus conterrâneos amantes da filosofia que queriam ouvir o, por suposto, afamado relato da confabulação mantida na casa de Pitodoros.

Segue-se, consequentemente, e isto não deixa de ser igualmente inusitado, que a versão escrita do Parmênides de Platão (versão do diálogo mantido entre Sócrates, Zenão e Parmênides) veio a ser, digamos - no que estamos formalmente de acordo com Proclo -, de

\footnotetext{
5 “Arquelau de Atenas, mestre de Sócrates" (DIELS \& KRANZ, Die Fragmente der Vorsokratiker, 6o A 7); “a Filosofia se restringia ao estudo da física e da ética <tò physikòn kai êthikón>” (Idem, p. 6o A 6). Mestre é traduzido de kathegêtês que tem o sentido, digamos, de "aquele que indicou o caminho ou que serviu de guia".
} 
quarta "memória". São, afinal, três transposições memorativas: de Pitodoros para Antífon, de Antífon para Céfalo e de Céfalo para Platão. O que, em última instância, se transpôs não foi propriamente o conteúdo dos escritos de Zenão (grammátonn), mas sim o conteúdo da discussão coloquial da diálexis entre Sócrates, Zenão e Parmênides realizada logo após a leitura feita por Zenão "dos escritos" do próprio Zenão. O fato inusitado ainda é que o debate não se estende aos escritos, e sim apenas a uma hipótese. "Terminada a leitura" - eis o que consta na escrita do Diálogo - Sócrates pediu a Zenão que relesse "a primeira hipótese do primeiro escrito - tèn próten hypóthesin toû prótou lógou”. Assim que Zenão releu, Sócrates perguntou: "o que queres dizer com isso?" (Prm. 127e). Daí que foi às voltas da "hipótese do primeiro escrito" que se desenrola todo o debate, do qual Antífon guarda em detalhes todo o suposto desenvolvimento argumentativo da discussão.

1.2 - Sobre a estada de Parmênides e de Zenão em Atenas, em geral, não se contesta e, portanto, é tida como verdadeira, ou seja, dá-se crédito histórico ao relato de Platão. O que está posto em dúvida, por imprecisão cronológica, é a presença de Sócrates nesta ocasião. $\mathrm{O}$ primeiro a questionar essa presença, foi Ateneu de Náucratis, um egípcio que viveu em Roma entre o final do século II e o início do III d.C. Foi ele, no Depnosofistas/Banquete dos sábios, quem pressupôs ser "muito difícil admitir que o Sócrates de Platão possa ter conversado com Parmênides, porque a sua juventude não o permitia ter acesso ou mesmo compreender uma tão sofisticada linguagem"

Eis o que consta no introito de Diálogo: "Parmênides já era bem idoso, de cabelos brancos (...) e deveria ter uns sessenta e cinco anos. Zenão se aproximava dos quarenta. Sócrates, naquela ocasião, era muito jovem (sphódra néon)" (Prm. 127a-c). Por essas indicações podemos inferir algumas datas e tecer algumas considerações. O dilema, a partir de Ateneu, veio a ser: se Parmênides tivesse a idade que Platão diz ter, Sócrates, que nasceu por volta de 470 a.C., no demos de Alopece, ainda não teria nascido. Se Sócrates estivesse de fato estado lá, então (isto é o que supomos), o encontro haveria de ter ocorrido por volta de 453/54 a.C., ocasião em que Sócrates, que viveu entre 470-399 a.C., teria por volta de uns 17/18 anos. A data de sua morte, 399, é bastante segura. Platão, na Apologia, fez o seguinte registro, como palavras de Sócrates: "pela primeira vez, com mais de setenta anos, compareço a um Tribunal" (Ap. $17 \mathrm{~d}$ ).

Mantendo-se, entretanto, a data de 530-460 a.C., em geral cifrada pela tradição como o período em que viveu Parmênides, então Sócrates, quando Parmênides morreu, teria apenas nove (9) anos, o que, de fato, daria sentido ao registro de Ateneu. Quer dizer: para que o encontro possa de fato ter ocorrido em 453/454 (como cabe e é preciso supor caso damos crédito ao que consta no Diálogo), então é preciso manter-se fixo o período em que Sócrates viveu, mas não o de Parmênides, que, para ter os 65 anos, teria que, de 530-460 a.C., ser modificado para 518-448 a.C. O que faz sentido: trata-se de uma data bem plausível, visto que levaria Sócrates para os 17/18 anos, e Zenão, conforme diz o Diálogo, teria por volta de 40 anos, o que colocaria seu nascimento entre 485-483 a.C., justamente dentro da cifra que, em geral, registra a tradição. E mais: colocaria Zenão como um coetâneo de Péricles (495429 a.C.), o que também faz sentido.

Platão, efetivamente, insiste neste encontro, do qual faz referência tanto no Teeteto quanto no Sofista. No Teeteto, ele põe na boca de Sócrates as seguintes palavras referidas a Parmênides: "Tive a oportunidade de vê-lo quando eu ainda era muito jovem (pánu néos) e ele já de idade avançada" (Tht. 183e). No Sofista, Platão põe igualmente como fala de Sócrates a seguinte assertiva: vou "empregar o método do interrogatório que, em dias

${ }^{6}$ Deip. XI, 505 F, apud. DIELS \& KRANZ, Die Fragmente der Vorsokratiker, 28 A 5. 
distantes, se serviu o próprio Parmênides ao desenvolver, já em idade avançada, e perante mim, ainda jovem (egò néos), maravilhosos argumentos" (Sph. 217c).

A tirar pela época em que o encontro entre Parmênides, Zenão e Sócrates se deu em Atenas, dois outros importantes personagens, mesmo que não estejam explicitamente referidos no Diálogo, também merecem consideração: Anaxágoras de Clazômenas (500-428 a.C.) e Péricles (495-429 a.C.). O primeiro, na ocasião do encontro, supondo-se que ele ocorrera por volta de 453/54 a. C., haveria de ter, pelas cifras que lhe são atribuídas, uns 47 anos; Péricles teria por volta de uns 40/42, e, portanto, seria um coetâneo de Zenão. Há, entretanto, relativo a Péricles, um testemunho de Plutarco, segundo o qual ele "se fez auditor do eleata Zenão"7. Pelo teor do relato de Plutarco fica claro que Zenão esteve efetivamente em Atenas, sem que isso permita afirmar que Péricles o ouviu naquela ocasião referida pelo Diálogo. Pelo que consta relativo a Parmênides, era a primeira vez que ele vinha a Atenas. Zenão, entretanto, por lá estivera em outra ou outras ocasiões. A esse respeito, no Primeiro Alcibíades, por exemplo, Platão assegura que Pitodoros e Cálias foram alunos de Zenão. Diz que "foi com o auxílio de Zenão que os dois findaram por ser sábios e ilustres, isso depois de cada um ter pago cem minas de honorários" (Alc. 1. 119a). Com certeza houve entre Zenão, Pitodoros e Cálias uma convivência, que se deu, não em Eleia , mas em Atenas, em cuja ocasião, certamente, também Péricles haveria de ter frequentado o ensino de Zenão.

A figura que aqui mais importa destacar, mais que a figura de Péricles, é a de Anaxágoras, visto que, afinal, é de Clazômenas, terra de Céfalo e de seus companheiros. Anaxágoras - eis o que mais importa - é tido, senão como o primeiro, ao menos o mais importante mentor, em Atenas, de uma Escola filosófica erigida sob o sustento político e econômico do governo Péricles. Da "escola" participaram Arquelau, mestre de Sócrates, e o próprio Sócrates, mestre de Platão. Mesmo protegido por Péricles, o exílio de Anaxágoras se deu por volta de 431, ocasião em que Sócrates haveria de ter uns 38 anos, e, sendo assim, estaria por volta de uns $\mathbf{2 1 / 2 2}$ anos distanciado do suposto encontro com Zenão e Parmênides. Naquela ocasião - isto é bom lembrar - Platão, que viveu entre os anos de 428348 a.C., ainda sequer tinha nascido. A mudança de Anaxágoras para Atenas, sob a proteção de Péricles, e a vinda de Parmênides e de Zenão para Atenas compõem uma contemporaneidade, visto que se deu mais ou menos na mesma época.

Se Parmênides e Zenão, entretanto, estiveram efetivamente em Atenas, como assegura o Diálogo, é de todo improvável que, inadvertidamente, Anaxágoras e Arquelau, inclusive Péricles ${ }^{9}$ e outros, deixaram passar tão extraordinária oportunidade de ouvir um dos mais louvados filósofos da Grécia: Parmênides, e, junto dele, Zenão. Anaxágoras, por certo, estivera por lá, não há como deixá-lo de fora, ainda mais que, naquela momento, ele, e não Sócrates, era o filósofo mais ilustre de Atenas. Sócrates era apenas um de seus discípulos e assíduo frequentador de suas lições, bem como das de Arquelau. A expressão - "Sócrates e alguns outros (Socrate kai állous tivàs)" - com a qual Platão se referiu aos que com Sócrates estiveram presente na casa de Pitodoros (Prm. 127C), por ser ambígua e aberta, permite pôr nela uns quantos personagens da época, mas não, evidentemente, qualquer um.

Deixando essa pressuposição de fora, o que importa destacar é o entrançamento dos personagens, que, por sua vez, representam linhagens filosóficas implícita e explicitamente

\footnotetext{
${ }^{7}$ PLUTARCO, Vies. Périclè-Fabius Maximus. Alcibiade-Coriolan, I, IV, 5.

${ }^{8}$ Diógenes Laércio registrou que Zenão preferiu viver em Eleia, que se estabelecer "na soberba Atenas" (2005, IX, 5, 28). Pelo teor do registro, Zenão certamente optou por Eleia depois de ter vivido algum tempo, ou seja, construído uma experiência de vida, mesmo que breve, em Atenas.

${ }^{9}$ Diodoro da Sicília fez de Anaxágoras “mestre de Péricles” (DIELS \& KRANZ, Die Fragmente der Vorsokratiker, 59 A 17).
} 
lembrados no Introito do Diálogo. Parmênides e Zenão representam a escola de Eleia, ou melhor, a linhagem eleática; Anaxágoras a linhagem Jônica, em particular a de Mileto. Eis o que registrou o pseudo-Galiano na sua História da Filosofia apud Diels \& Kranz: "Anaximandro preparou Anaxímenes que veio a ser o mestre de Anaxágoras, que, enfim, trocou Mileto por Atenas, onde fez de Arquelau o primeiro ateniense iniciado na filosofia" ${ }^{\text {. }}$ Anaxágoras, portanto, mantinha um forte vínculo com a linhagem filosófica de Mileto (cidade, aliás, da qual Péricles repatriou Aspásia, que, em Atenas, veio ser uma eminente professora de Retórica, inclusive de Sócrates, de Alcibíades e de Péricles do qual findou por ser a esposa). Além de representar a linhagem Jônica, Anaxágoras representa igualmente, com a participação de Arquelau e do jovem Sócrates, o germinar do desenvolvimento de uma tendência do filosofar imperante em Atenas. Cabe aqui, enfim, como ilustração, o que escreveu, no Stromateîs, Clemente de Alexandria: "Depois de Anaxímenes, veio Anáxagoras de Clazômenas (...), que transpôs da Jônia para Atenas o ensinamento filosófico, e que teve como sucessor Aquelau, do qual Sócrates foi discípulo"11.

É, enfim, bem característico da obra platônica o referido entrelaçamento de personagens e de linhagens filosóficas. Assim, por exemplo, como Platão põe Sócrates, no Parmênides, como um auditor dos escritos de Zenão (Zénonos grammátonn), no Fédon, faz dele, também "ainda jovem”, um auditor dos escritos de Anaxágoras. Lá no Fédon, sob estilo igualmente aberto e impreciso, diz Platão que Sócrates "ouviu alguém ler um livro que dizia ser de Anaxágoras" (Phd. 97b-d), de cuja leitura Sócrates supôs ter encontrado a explicação da causa inteligível, ou seja, do um explicativo de tudo o que existe. Daí que, a respeito da tematização filosófica do "um", Platão faz de Sócrates auditor não só dos escritos de Zenão (elaborados tendo em vista defender a doutrina de Parmênides) como também dos escritos de Anaxágoras.

É evidente, portanto, o enlaçamento (verdadeira estromatê̂s platônica), e, com ele, a anábasis (a incursão) histórica promovida por Platão ao interior do desenvolvimento histórico da Filosofia, em particular da filosofia da phýsis, que, historicamente, se desdobrou em filosofia do kósmos e filosofia da pólis. Tal entrelaçamento e anábasis se estendem por toda a obra platônica, e se constitui num método heurístico mediante o qual Platão, o remodelador do éthos grego, põe o seu filosofar na senda do passado, a fim de com ele fazer renascer o presente ajustando-o em vista de novos horizontes abertos em busca do saber. Ao modo da Fênix, a obra platônica tem em tudo por meta fazer renascer o passado no presente, o velho, no novo, e assim regenerar o arcaico sob novos parâmetros de idealidade. O passado, entretanto, o velho e o arcaico, que a obra platônica tende em tudo a regenerar diz respeito não a uma arqueologia, e sim a uma teleologia construída sob a análise do passado imerso no presente, cuja realidade, fecundada por idealidades do passado, faz do hoje, ou seja, da realidade de agora, daquela que germina o amanhã, velha e arcaica. Daí igualmente porque a obra platônica é tão realista quanto idealista e, além disso, aberta, conciliatória e não dogmática.

1.3 - Zenão e Parmênides estavam "hospedados na casa de Pitodoros, para além dos muros, no Cerâmico". Cerâmico era o nome da região, rica em argila, que abrigava as olarias, as oficinas do artesanato, cujo nome findou por se associar aos produtos e às artes, ditas de cerâmica, ali produzidas. O nome, entretanto, Cerâmico foi derivado, tal como consta em Pausânias, do herói Ceramo, do qual se dizia ser filho de Dioniso (o Baco dos latinos) e de

${ }^{10}$ DIELS \& KRANZ, Die Fragmente der Vorsokratiker, 59 A 7.

${ }^{11}$ Strom. I, 63, apud DIELS \& KRANZ, Die Fragmente der Vorsokratiker, 59 A 7. 
Ariadne, esposa de Dioniso ${ }^{12}$. A região do Cerâmico, tal como consta em Tucídides, História da Guerra do Peloponeso (II, 34), se estendia em frente ao grande Pórtico de entrada de Atenas, cortado por uma grande avenida que ia do Pórtico ao Demos de Academos, justo naquele em que Platão sediou a Academia. Margeando as laterais da grande avenida, encontrava-se o mais importante cemitério de Atenas, no qual eram enterrados os heróis de guerra e outros nobres. A avenida do Cerâmico, em Atenas, veio a ser o protótipo, em Roma, da Via Appia, lugar em que os romanos, imitando os gregos, passaram a enterrar seus nobres e seus heróis, cujos túmulos muitos deles ainda hoje lá se encontram. Lá também, na Via Appia, assim como no Cerâmico foram morar, em grandes mansões os ricos quer da antiga Roma quer da antiga Atenas, e por uma razão bem simples: porque, estando ali "descansando" os nobres e os heróis, era o lugar mais protegido e seguro que um grego ou um romano poderia encontrar.

Foi para lá, para o Cerâmico, que "Sócrates e alguns outros" se dirigiram, e com um objetivo bem preciso: "ouvir a leitura dos escritos (tôn grammátonn) de Zenão, que, pela primeira vez, eram apresentados em Atenas" (Prm. 127a-c). Da parte de Zenão, pelo que consta no Diálogo, seu objetivo consistia em combater por escrito os contraditores da principal tese de Parmênides segundo a qual a hipótese do Um propícia bem menos consequências absurdas que a do Múltiplo. A iniciativa desse embate público em favor de seu mestre tinha também uma justificativa: os referidos escritos de Zenão foram roubados, e isso ainda antes (segundo ele diz) de estarem filosoficamente acurados, e que, bem por isso, acabaram promovendo grandes mal-entendidos. Daí a razão pela qual Zenão, fazendo-se acompanhar de Parmênides, se deslocou até Atenas, e o fez unindo o útil ao agradável, ou seja, justamente numa das grandes Panateneias $^{13}$, ocasião em que para lá se dirigiam intelectuais de todos os cantos, de modo que se constituía no melhor momento e lugar para Zenão exercitar publicamente o seu intento.

Os escritos a serem lidos eram, sim, de Zenão, mas versavam sobre a doutrina de Parmênides. Eram escritos com uma finalidade bem específica: fazer uma defesa apaixonada da doutrina do mestre. Tratava-se, pois, de escritos de defesa, e, consequentemente, de contestação, que, portanto, se constituíam num conjunto de argumentos relativos ao tema do um. Por ser, entretanto, de contestação, disso se segue, que, na época, as teses de Parmênides produziram muita controvérsia, sobretudo mal-entendidos, que não devem, com certeza, serem reputados somente a Zenão e ao mal acabamento de seus escritos. Escritos, como já foi assinalado, roubados antes de que o próprio Zenão, como ele mesmo diz, "decidir se os tornaria público ou não"; e tem mais: tratava-se de escritos que foram elaborados (como também diz Zenão a Sócrates) movidos "por um amor juvenil à controvérsia (hypò nèou philonikías), e não "por um desejo amadurecido de prestígio" (Prm. 128d-e). São palavras que Platão põe na boca de Zenão dotadas de senso explicitamente metodológico, em termos de, por exemplo, não desqualificar diretamente a doutrina

\footnotetext{
12 "Desde las puertas hasta el Ceramico hay porticos y delante de ellos estatuas de bronce de mujeres y hombres que por algun motivo fueron famosos. (...). El lugar del Ceramico tiene este nombre por el heroe Ceramo, del que se dice que es hijo de Dioniso y de Ariadna" (PAUSÂNIAS, Descripción de Grecia, p.90-91).

${ }^{13}$ Nome das festas ditas grandes quadrienais, coincidentes com a Olimpíada. Assim como as ditas pequenas, ou seja, as Ateneias, elas eram realizadas em honra da deusa Palas Atena: deusa da sabedoria e protetora da Ática. Em tais festas vinculavam-se celebrações religiosas com gastronômicas, com eventos atléticos, com concursos de poesias e de música, etc. Eram gastronômicas por conta das oferendas e dos animais imolados em sacrifício: os gregos não desperdiçavam nada, e tudo era festivamente partilhado e consumido. As panateneias, pelo que o próprio nome diz (em que pan faz referência ao todo), congregavam em Atenas, além de intelectuais, poetas, filósofos e artistas, reunia também governantes e representantes de todas as póleis, de modo que, além de promover celebrações universais da própria cultura grega, promoviam igualmente a confraternização e o entendimento entre as póleis.
} 
filosófica dos dois extraordinários mestres de Eleia, e, claro, do consuetudinário filosófico grego.

Trata-se aqui - é o que supomos - de um método que nos remete, por exemplo, aos exercícios dialéticos praticados pelos escolásticos na atividade acadêmica como forma de se esquivar da subordinação à ortodoxia religiosa da época. A estratégia funcionava assim: sempre que um professor, em função de suas opiniões teológicas pouco ortodoxas, era chamado a prestar contas a uma autoridade eclesiástica, sempre se desculpava dizendo que as sustentava sem a preocupação de demonstrar se eram verdadeiras ou falsas, e sim apenas promover o exercício escolar da disputa dialética (gratia exercitii, probabiliter o disputationis causa $\left.^{14}\right)$. Lá em Zenão, na assertiva do diálogo, e, segundo palavras dele, "fiz por amor juvenil à controvérsia", soa aproximadamente nos mesmos termos, como se ele quisesse preventivamente angariar de Sócrates benevolência crítica. Entretanto, o mesmo Zenão não é assim tão benevolente com o próprio Sócrates, ao qual, sem rodeios, acusa de não entender bem o sentido de sua obra:

Sim, Sócrates, teria dito Zenão, tu não entendeste o verdadeiro sentido da minha obra... O meu intento é defender a tese de Parmênides contra os que pretendem ridicularizá-lo. É um escrito de combate (...), com a intenção manifesta de mostrar como decorrem consequências muito mais absurdas da hipótese do Múltiplo, por eles defendida, que da hipótese do Um... (Prm. $128 \mathrm{c}-\mathrm{d})$.

Aqui está o cerne da questão. Mas, ainda quanto ao arranjo cênico do Prólogo do Diálogo, cabe antes considerar que, assim que Zenão procedeu à leitura de seus escritos, consta que, nesse momento, ali estiveram presentes apenas "Sócrates e alguns outros" de sua companhia. Quer dizer: naquele justo momento, tendo em vista o fato de ter Zenão e Parmênides vindo de tão longe, com tantos intelectuais presentes na Panateneia, o público parece bastante minguado, restrito. No momento da leitura, Parmênides e Pitodoros estavam casualmente fora do recinto. Ambos retornaram "quase no fim", quando Pitodoros, o anfitrião, "entrou acompanhado de Parmênides e daquele Aristóteles que mais tarde veio a ser um dos trinta" (Prm. $127 \mathrm{~d}$ ) ${ }^{15}$. "Mais tarde" significa no ano de 404 a.C., logo após a guerra do Peloponeso ${ }^{16}$, em que Atenas se submeteu (mesmo que por curta duração, apenas um ano) a uma cruel tirania de magistrados, quase todos conhecidos e muitos deles parentes, caso de Cármides e Crítias, o primeiro tio, o outro primo em segundo grau de Platão ${ }^{17}$.

Assim que Pitodoros e Parmênides, acompanhados do referido Aristóteles, retornaram, o Diálogo apresenta, em vista da ausência e atraso, apresenta a seguinte justificativa: "Pitodoros ouvira antes, do próprio Zenão" (Prm. 127d)! Daí que é de se supor que, naquela ocasião, Zenão leu (apresentou publicamente) seus escritos mais de uma vez. Por certo não leu só para Pitodoros, e sim para um outro público. O fato é que - tal como relata Antífon - terminada a leitura, Sócrates pede a Zenão que releia "a primeira hipótese do primeiro argumento”, e, em cima desta hipótese, que começa o debate, a diálexis entre Sócrates, Zenão e Parmênides.

Não podemos aqui deixar de realçar que o Introito do Diálogo destaca dois eventos entre si bem distintos: um, o encontro de Zenão e Parmênides com Sócrates e os de sua companhia (ocorrido, como pressupomos, por volta de 453/54 a.C.); outro, bem mais tarde,

\footnotetext{
${ }^{14}$ SPINELLI, Herança Grega dos Filósofos Medievais, p.152 et seq.

${ }^{15}$ Diógenes Laércio faz menção ao referido Aristóteles como sendo "um governante (politeusámenos) ateniense, autor de agradáveis discursos forenses” (DIÓGENES LAÉRCIO, Vite e dottrine dei più celebri filosofi, V, 1, 35).

${ }^{16}$ Cf. XENOFONTE, Helénicas, p.74.

${ }^{17}$ Cf. Carta VII, 324 a.
} 
o encontro de Céfalo e seus acompanhantes, primeiro, com os dois irmãos de Platão no Mercado, depois com Antífon, na casa de Antífon, onde foram especificamente para ouvir do mesmo Antífon o relato do relato de Pitodoros sobre o debate (a diálexis) construído a partir da releitura da "primeira hipótese do primeiro argumento" que Sócrates pediu a Zenão que relesse.

São, com efeito, dois eventos distintos. Entretanto, o Diálogo em si mesmo, ou seja, aquele grafado por Platão, se constitui ele próprio num terceiro evento: $1^{\circ}$ ) Zenão leu seus escritos para "Sócrates e alguns outros", e, assim que terminou, começou o debate; $2^{\circ}$ ) Céfalo e seus compatriotas, assim que chegam na casa de Antífon, se cumprimentaram e logo pediram que relatasse as conversações. Antífon, a princípio relutou, seria muito cansativo, mas, sem demora, fez, de memória, uma longa exposição; $3^{\circ}$ ) a grafia do relato das conversações, feita por Platão, e que se inicia exatamente assim: "Antífon disse que Pitodoro disse...".

São, portanto, vários registros: $\mathbf{1}^{\mathrm{o}}$ ) o registro memorativo de Pitodoros; $2^{\mathrm{o}}$ ) o registro de Antífon guardado na memória "depois de repetidas vezes ouvir o relato de Pitodoros"; $3^{\mathbf{o}}$ ) a audição (o registro memorativo) de Céfalo a partir da exposição memorativa de Antífon; $4^{\circ}$ ) o registro gráfico (por escrito) de Platão, cuja grafia - isso é muito importante de ser realçado - é apresentada como sendo feita (fruto) a partir de um relato de Céfalo. É assim, afinal, que Platão dá início ao todo do Diálogo, como sendo uma fala de Céfalo: "Estando em Atenas, vindos de Clazômenas, onde residimos, encontramos na Ágora Adimanto e Gláucon" (Prm. 126a).

Aqui até poderíamos dizer que o diálogo, o Parmênides, grafado por Platão é fruto de pura oralidade, mas isso pode não ser plenamente verdadeiro. Dá-se que não podemos de modo algum desconsiderar os escritos de Zenão. Afinal, quando ele esteve na casa de Pitodoros levou consigo cópia de tais escritos, que, além de ler, deve tê-los difundido, propagado em manuscritos - hábito bastante comum entre os intelectuais gregos. Por suposto não eram os escritos que foram roubados, ou seja, aqueles que foram elaborados, como o próprio Zenão disse, movido "por amor juvenil à controvérsia", e sim textos reescritos, amadurecidos, ou seja, aptos para serem intencional e livremente dados a público, e, consequentemente, angariar ou não prestígio.

Quer dizer: mesmo que o diálogo sob o registro da grafia platônica acentua a oralidade e a transmissão mnemônica, de modo algum dá para excluir o acesso de Platão aos referidos escritos, que, pelo que consta, se constituíam num rol de argumentos. No entanto, como já referido, o diálogo o Parmênides não se ocupou em reproduzir os escritos, ou seja, o conjunto do livro de Zenão, e sim o debate que se concentrou na "primeira hipótese do primeiro escrito ou argumento". Há, até diríamos, um agravante no sentido de que a "hipótese do primeiro argumento" não é reproduzida com palavras de Zenão, e sim de Sócrates, concebidas a partir de Zenão.

Estas são as palavras (na tradução de Carlos Alberto Nunes):

Que queres dizer com isto, Zenão? Se os seres são múltiplos, por força terão de mostrar, a um só tempo, semelhanças e dissemelhanças, o que não é possível. Nem o semelhante pode ser dissemelhante, nem o dissemelhante semelhante. Declaraste isso mesmo, ou fui eu que não compreendi direito? Isso mesmo, respondeu Zenão $(\operatorname{Prm} .127 \mathrm{e})^{18}$.

\footnotetext{
${ }^{18}$ Citamos aqui a tradução de M. Iglésias e F. Rodrigues: “Que queres dizer com isso, Zenão? Que, se os seres são múltiplos, então é preciso que eles sejam tanto semelhantes quanto dessemelhantes, mas que isso é impossível, pois nem as coisas dessemelhantes podem ser semelhantes nem as semelhantes, dessemelhantes? Não é isso que queres dizer? É isso mesmo disse Zenão" (Prm. 127 e).
} 
Aqui começa o dificultoso imbróglio da discussão a respeito do um e do múltiplo: um tão entranhado debate que mereceu dos próprios personagens alguns comentários. Zenão, por exemplo, dirigindo-se a Sócrates aconselha-o a agir "ao modo dos cães farejadores de Esparta" caso quisesse efetivamente "descobrir e trilhar a pista do discurso" a respeito do um e do múltiplo com o qual estavam se ocupando (Prm. 128c). O próprio Parmênides, na medida em que se dispõe a entrar no debate, compara a si próprio com "o cavalo de Íbico", que, outrora, fora um grande campeão de corridas, e que, agora, não tinha tanto fôlego para se lançar a "um jogo tão cansativo" (Prm. 137b). A tirar, portanto, pela força das expressões proferidas por filósofos tão celebrados, tal como Parmênides, Zenão e Sócrates, isso mostra o quanto o tema do um e do múltiplo era desafiador, e, sobretudo, o quanto intrigava a mente dos filósofos tradicionais.

Entra aqui ainda uma outra questão: a de que o diálogo o Parmênides não se restringe ao status quo do debate restrito à época em que supostamente se deu a leitura feita por Zenão seguida da discussão entre Zenão, Sócrates e Parmênides na casa de Pitodoros. O diálogo comporta um status quaestionis que ultrapassa Zenão e Parmênides, e que, portanto, vai além dos postulados restritos aos eleatas, visto que tende a englobar o debate "atual" da Academia, ou seja, pertinente ao momento ou momentos em que o tema entrou na pauta da discussão e findou, através de Platão, por ser redigido.

Daí a razão pela qual, como já visto, o diálogo comporta um introito que ultrapassa, ou seja, vai igualmente além dos termos da questão teórica com a qual o diálogo se move. Ele é bem mais que um simples prólogo. Dá-se que, mais do que conter um logos introdutório atinente à tratativa do diálogo, ele põe em prática o método da anábasis (da incursão) ao interior do desenvolvimento histórico da Filosofia mediante o qual dá ênfase à extensão e ao percurso histórico da tratativa. Sob a referência de duas póleis - de Clazômenas e de Eleia - o diálogo põe em evidência o esplendor de duas grandes regiões, a da Magna Grécia e a da Jônia, e, com elas, a amplitude do kósmos histórico do filosofar que acaba, enfim, por se concentrar e tomar novo alento na Ática, em Atenas.

A Magna Grécia, no contraposto da Jônia, representava, numa perspectiva grega, o Mundo Novo. Foi no mundo novo, portanto, que a Filosofia encontrou uma extraordinária prosperidade. Mas agora, era no velho mundo de Atenas, que ela vinha a renascer sob um novo alento, e justo a partir de um jônico: de Anaxágoras de Clazômena. Ambas, a Magna Grécia e a Jônia, foram centros extraordinários sob vários aspectos: geográfico, geopolítico, administrativo, econômico e cultural. Dentro do contexto da Magna Grécia, Eleia, se comparada, por exemplo, a Crotona e a Taranto, cidades nas quais a Escola (a linhagem) Pitagórica prosperou, foi na verdade uma pólis bem restrita e modesta. $\mathrm{O}$ mesmo não se pode dizer de Clazômenas, que, entretanto, não comportava o mesmo esplendor de Mileto.

Em Eleia prosperaram três nomes - Xenófanes, Parmênides e Zenão - que fizeram história no contexto da cultura e da filosofia grega. Com eles, Eleia se projetou como um dos mais importantes centros irradiadores de saber por toda a Grécia, com extraordinária influência em toda a Filosofia posterior. Eles fomentaram, inclusive, uma linhagem filosófica - um génos ex Eléas, na expressão de Platão (Sph. 216a) -, que igualmente se projetou como um plus perante os pitagóricos, e findou, inclusive, por contribuir, através de Filolau de Crotona e de Arquitas de Taranto para uma profunda renovação interna do próprio pitagorismo. O curioso é que na base da linhagem eleática está um jônico, Xenófanes de Cólofon, e, na dos pitagóricos, um outro jônico, Pitágoras de Samos.

Platão, ainda jovem, circulou por aquela região: por Taranto e por Crotona. Diz a tradição que "Filolau de Crotona é o autor dos escritos pitagóricos", que Platão "pediu, numa carta a Dion, que lhe comprasse". Diz ainda que foi a partir desses escritos que ele "escreveu 
o Timeu"19. No Sofista, referindo-se ao filósofo Parmênides, Platão o denominou, respeitosamente, de "nosso pai - tòn tou patrós" (Sph. 241d): nosso, por ser não só dele, mas também de Sócrates e de toda a filosofia pós Parmênides, na qual, inclusive, se inclui Aristóteles. Platão, pelo que consta, esteve também em Megara, cidade de Euclides, daquele que se ocupou em arranjar uma linhagem filosófica casando proposições de Parmênides com as de Sócrates.

Eis o relato:

Aos vinte e oito anos, segundo Hermodoro, Platão retirou-se para Megara com outros discípulos de Sócrates, indo juntar-se a Euclides. Em seguida, prosseguiu para Cirene, ao encontro do matemático Teodoro, e de lá foi para a Itália onde se encontrou com os pitagóricos Filolau e Euritos; da Itália viajou para o Egito em visita aos profetas... ${ }^{20}$

Há um círculo que se fecha no contorno das duas referidas grandes regiões - da Jônia e da Magna Grécia - resultando que a Filosofia grega partiu da periferia para centro, e não o contrário. Da Jônia, a principal pólis era Mileto na qual floresceu a tríade de filósofos (Tales, Anaximandro e Anaxímenes) que vieram a ser os primeiros mestres da Filosofia e da Ciência grega. Nas proximidades, um pouco acima, temos a ilha de Samos, na qual floresceram Pitágoras e Melisso, e mais tarde Epicuro. Logo na sequência geográfica vem Éfeso, terra de Heráclito, com a qual a filosofia de Parmênides, apesar das distâncias e das diferenças, mantém grandes ligações. Acima de Éfeso, vem Cólofon, terra de Xenófanes, um dos fundadores de Eleia e mestre de Parmênides. Um pouco mais acima vem Clazômenas, terra de Anaxágoras (primeiro mestre de Atenas), de onde partiu Céfalo com seus companheiros em busca de Anfífon, a fim de ouvir o relato das teses filosóficas dos eleatas.

O velho e o novo se confluem. Trata-se, aliás, de uma confluência (em termos de uma dialética) que veio a se constituir numa caraterística bem própria da dialógica platônica. Trata-se, pois, de uma dialética bem ao estilo platônico, mediante a qual o passado e o presente são concebidos imersos um no outro em que o passado dentro do presente se move numa perspectiva de um continuo renascimento em vista de um futuro sempre melhor (do béltistos). É sob esse viés histórico, inerente ao qual Platão conflita a realidade e a idealidade, que a sua dialógica comporta, enquanto método, uma permanente anábasis ${ }^{21}$, ou seja, um retorno continuo para dentro dos caminhos (do território) da própria Cultura grega, cuja imersão (no sentido de um voltar-se para dentro de si efetivado no presente) haveria de continuamente fazer ressurgir, sob o signo de uma constante revisão, o passado, sob novos parâmetros de melhoria presente. Daí que o próprio introito do Diálogo comporta essa anábasis visto que, de um lado, se reporta a um Parmênides "bem idoso", de outro, a um Zenão de "meia idade", e enfim, a um Sócrates "bem jovem". O inusitado dessa dialética do "bem idoso" e do "bem jovem" está no fato de ela ser concebida por um Platão (quando grafa o Diálogo) supostamente de "meia idade", já instalado na maturidade, ou seja, ele próprio numa fase de revisão da própria vida e da própria obra filosófica.

Aqui não dá, enfim, para olvidar que o Sócrates "bem jovem" do Diálogo, ao mesmo tempo em que representa o jovem Sócrates histórico, coincide com o jovem Sócrates enquanto metáfora do projeto filosófico de Platão, que, disponibilizado para os gregos, se vê na iminência de ser tragado pelos ideias unificadores da Macedônia. Dá-se que, por volta de

\footnotetext{
${ }^{19}$ DIELS \& KRANZ, Die Fragmente der Vorsokratiker, 44 A 1. Até Galileu refere-se por duas vezes a Filolau como "mestre de Platão": uma na Carta à Senhora Cristina de Lorena; outra, nas Considerações sobre a opinião copernicana.

${ }^{20}$ DIELS \& KRANZ, Die Fragmente der Vorsokratiker, 44 A 5.

${ }^{21}$ SPINELLI, Ética e Política: a edificação do éthos cívico da paideia grega, p. 412ss.
} 
350 (Platão morre em 348), a força do poder do Império macedônico já se manifestava explicitamente por toda a Grécia. Daí a necessidade de igualmente concebermos toda a aporia com a qual se debate o Diálogo entre semelhantes (hómoiá) e dissemelhantes (anómoia), o paradoxo entre o um e o múltiplo, dentro de uma dialógica que finda por resultar num retrato iminente do futuro da própria Cultura grega, e, consequentemente, do devir da própria Grécia: daquela que, nos termos de uma geo-metria relativa à sua própria identidade, concebida como um todo múltiplo, é pensada como diferente dela mesma enquanto um todo único.

Dá-se que, primeiro, não havia, e não houve efetivamente, naquela ocasião, ou seja, quando o todo grego começou a ser submetido aos ideais helênicos unificadores da Macedônia, um logos que estava, ou estivesse, em condições de mesurar uma identidade relativa ao ser grego; segundo, e em definitivo, a Grécia real, de múltiplas identidades, cada pólis com sua politeía, de modo algum se conformava com os parâmetros de uma Grécia ideal submetida a uma única identidade fechada, dogmática, dentro dos ideais unificadores da Macedônia.

Tendo a filosofia platônica como característica fundamental - que, aliás, é uma característica da própria Filosofia - a racionalidade aberta, a perspectiva iminente de uma racionalidade fechada (dogmática) se impunha como antídoto e morte quer do filosofar platônico quer da própria Filosofia. Daí que o diálogo o Parmênides vem a ser o prenúncio e nisto está toda a sua complexidade - de que o um não poderia jamais asfixiar (matar) o múltiplo, uma vez que é dele que ele retira a sua própria subsistência, sua força e sua vida. $\mathrm{O}$ um que suprimisse a multiplicidade asfixiaria a si mesmo, e, sendo assim, ele só teria uma saída: acoplar-se à pluralidade de modo a continuamente se deixar envolver por ela, a fim de retirar dela o seu vir a ser e sua existência, numa dialética tal em que, da pluralidade, o um vem a ser, enfim, a causa. Dá-se que há - em termos de que deve haver - uma profunda reciprocidade entre o um e o múltiplo, sem a qual ambos perecem: o um sem a fertilização da pluralidade resulta tirânico, e, a pluralidade, sem a fertilização (feito um princípio de movimento) do um, se decompõe enquanto unidade. Trata-se de um movimento de geração mediante o qual o um e o múltiplo estão destinados a proporcionar reciprocamente uma unidade de mistura de contrários, sem o que, sob todos os aspectos, quer da vida do Cosmos, quer da vida animal, quer da vida humana, não há geração.

\section{Possibilidades de leitura e de interpretação do Parmênides}

Não dá para deixar de lado, mesmo que sob uma reflexão ligeira, o introito da intrincada discussão relatada por Platão no Parmênides a respeito do um e do múltiplo. Tomemos como ponto de partida desta breve reflexão a "hipótese do primeiro escrito" reproduzida, ou melhor, enunciada, no prólogo do debate, com palavras de Sócrates, nos termos supracitados e conforme as traduções, de Carlos Alberto e de Maura e Fernando:

a) De Carlos Alberto:

Que queres dizer com isto, Zenão? Se os seres são múltiplos, por força terão de mostrar, a um só tempo, semelhanças e dissemelhanças (sic), o que não é possível. Nem o semelhante pode ser dissemelhante, nem o dissemelhante semelhante. Declaraste isso mesmo, ou fui eu que não compreendi direito? Isso mesmo, respondeu Zenão (Prm. 127e);

b) De M. Iglésias e de F.Rodrigues: 
Que queres dizer com isso, Zenão? Que, se os seres são múltiplos, então é preciso que eles sejam tanto semelhantes quanto dessemelhantes (sic), mas que isso é impossível, pois nem as coisas dessemelhantes podem ser semelhantes nem as semelhantes, dessemelhantes? Não é isso que queres dizer? É isso mesmo disse Zenão (Prm. 127e).

Comparando uma tradução com a outra é possível fazer as seguintes observações:

$1^{\text {a })}$ Ambas, a de Carlos Alberto e a de Maura e Fernando verteram em português a assertiva grega "ei pollá esti tà ónta" por "se os seres são múltiplos" de modo que optaram por traduzir pollá por múltiplos, concebendo-a sob a forma de um adjetivo derivado de polýs e não de um advérbio no sentido de muitos. "Ei" é uma conjunção condicional que comporta o sentido de "se" ou "no caso de", de modo que "ei pollá" expressa uma hipótese, que, entretanto, comporta uma consequência inevitável: "se os seres são múltiplos", então, necessariamente etc. Ambos também verteram tà ónta por os seres, se bem que as duas traduções tendem, em outras assertivas, a substituir "os seres" por "as coisas", como nesta, por exemplo, de Maura e Fernando: "se é impossível as coisas dessemelhantes serem semelhantes (...) é impossível haver coisas múltiplas”. Tà ónta merece ainda uma observação: foi a partir dos escolásticos que tà ónta veio a ser latinizado por entia ("os entes" ou "os existentes") e o tò ón por ens, em decorrência, sobretudo, das traduções tardias da Metafísica de Aristóteles, na qual ele deu ao tò ón (ao conceito dito pelos escolásticos de ente) uma significação bem mais abrangente que o tò ón de Platão.

$2^{-}$) Na sequência da assertiva, "Se os seres são múltiplos - ei pollá esti tà ónta", vem a seguinte proposição, "họs ára dê̂ autá hómoia te eínai kaì anómoia”, traduzidas sob perspectivas que permitem distintas interpretações: a) a de Carlos Alberto: "Se os seres são múltiplos, por força deverão mostrar, a um só tempo, semelhanças e dissemelhanças..."; b) a de Maura e Fernando: "Que, se os seres são múltiplos, então é preciso que eles sejam tanto semelhantes quanto dessemelhantes...". Confrontando as duas versões o diferencial recai quanto aos predicados da semelhança e da dissemelhança. Do seguinte modo: a) a de Carlos Alberto assevera que "Se os seres são múltiplos, por força deverão (dê̂ = é forçoso, necessário) mostrar (eínai), a um só tempo" as semelhanças (ou seja, o que tem em comum, igual, concordante) e as dissemelhanças (o que não tem em comum, diferente, discordante); b) a de Maura e Fernando "Que, se os seres são múltiplos, então é preciso (deî = é necessário) que eles sejam (eínai) tanto semelhantes quanto dessemelhantes”. Comparativamente, a versão de Carlos Alberto assevera que "se os seres são múltiplos", então deverão necessariamente mostrar, a um só tempo, ou seja, de uma só vez, simultaneamente, semelhanças e dissemelhanças; a de Maura e Fernando, que, "se os seres são múltiplos”, então eles deverão ser tanto quanto, ou seja, supomos que em proporções idênticas (?), o ser semelhante e o ser dissemelhante;

$3^{\mathrm{a}}$ ) A duas traduções, mesmo que plausíveis, leram eínai (presente infinitivo de eimí = ser) de modo distinto. A de Carlos Alberto Nunes priorizou (no que concerne à chamada ontologia grega $^{22}$ ) a perspectiva empírica mediante a qual eînai (= ser) diz respeito àquilo que se mostra, ou seja, que se põe perante nosso campo de observação empírica em consonância com os vários modos (temos cinco modos) sensíveis com os quais "tateamos" o que nos cerca (tateamos visto que carecemos da alfabetização e da nomeação para começar a falar algo a respeito do que percebemos pelos sentidos). A de Maura e Fernando priorizou a perspectiva intelectiva mediante a qual, dentro da suposta ontologia grega, eînai verbaliza

\footnotetext{
${ }^{22}$ O termo, quer como substantivo (ontologia) quer como adjetivo (ontológico), é incomum na linguagem filosófica grega. Entretanto, é muito utilizado, e, muitas vezes, sobrepondo aos gregos a mentalidade escolástica que o gerou.
} 
(para não dizer predica, visto que teríamos que sobrepor à Platão uma mentalidade aristotélica) o ser no sentido de aquilo que é, daquilo, ou seja, de um algo abordado somente através do logos intelectivo, que em si (referido como ser) contém ou preserva;

$\left.4^{\mathrm{a}}\right)$ Em ambas as traduções segue a negativa condizente com o texto grego (toûto dè dè adýnaton). Na de Carlos Alberto Nunes, nestes termos: "Se os seres são múltiplos, por força terão de mostrar, a um só tempo, semelhanças e dissemelhanças, o que não é possível"; e assim na de Maura e Fernando: "Que, se os seres são múltiplos, então é preciso que eles sejam tanto semelhantes quanto dessemelhantes, mas que isso é impossível"23. Nas duas assertivas, cuja dificuldade não diz respeito à tradução, mas ao texto, a negativa não está claramente direcionada a um sujeito, de modo que permite a seguinte questão: é impossível exatamente o quê? Que os seres ou as coisas (tà ónta) poderão (conforme a tradução de Carlos Alberto) "mostrar, a um só tempo, as semelhanças e as dissemelhanças"? Ou que (conforme Maura e Fernando) é impossível que os seres ou as coisas sejam tanto semelhantes quanto dissemelhantes"? Sendo assim, então é permitido inferir que os seres poderão mostrar semelhanças e dissemelhanças, mas não a um só tempo, e sim em tempos diferentes?! Ou ainda, que é impossível ser tanto semelhantes quanto dissemelhantes, sendo possível ser apenas semelhantes e dissemelhantes - sem que, na proposição, entretanto, se saiba exatamente o que significa este tanto quanto: seria tanto quanto no sentido de proporção, ou de quantidade, ou de qualidade, ou de intensidade ou de dosagem etc.?

$5^{\text {a) }}$ Sem a sequência da explanação de Sócrates, feita no intuito de entender o argumento de Zenão, a primeira assertiva restaria indecifrável, justo porque os predicados semelhantes e dissemelhantes - não estão claramente direcionados a um sujeito: se plural (tà ónta) ou se singular (tò ón), mesmo que, efetivamente, o sujeito da assertiva seja plural. Quer dizer: o sujeito da frase são os seres (tà ónta = as coisas), mas os atributos relativos ao que é semelhante e ao que é dissemelhante, pelo que consta na sequência, se aplicam não aos seres ou às coisas em geral, e sim ao ser ou à coisa em particular. Ocorre que os seres, de um ponto de vista empírico e singularmente considerados, ou seja, imersos em nosso campo de observação, efetivamente para nós se mostram entre si semelhantes (iguais ou concordantes ou análogos) e dissemelhantes (desiguais ou discordantes ou díspares) de modo que é pelo sensível que os concebemos como múltiplos. O mesmo, entretanto, não se aplica ao escrutínio do intelecto, que, do ponto de vista dito "ontológico", não opera com o múltiplo (com o tà ónta plural), e sim com o um (com o tò ón singular, com o que está sendo, tò eón ${ }^{24}$ ) no qual o semelhante e o dissemelhante pode (ou se deixa) ser intelectivamente considerado. Mas, enfim, em dependência dos termos com os quais Sócrates enuncia a tese de Zenão, o que importa aqui destacar é que o escrutínio (o exame minucioso) intelectivo das coisas existentes, não se atém ou se restringe aos parâmetros do sensível mediante o qual o ser pode, simultaneamente, se apresentar como sendo assim (semelhante) ou não sendo assim (dissemelhante). O intelecto humano pode, sim, considerar o ser como sendo de tal modo (como sendo assim) ou então considerar o ser como não-sendo de tal modo (como não-sendo assim), porém em momentos diferentes, e não ao modo enganoso dos sentidos em que o ser (ou algo) se deixa considerar (por força de suas qualidades sensíveis, muitas vezes discordantes ou até mesmo contraditórias entre si, por exemplo, pequeno e grande, duro e mole etc.) como sendo múltiplo e em movimento;

6a) A aporia do argumento de Zenão parece se construir (do ponto de vista de Sócrates) da seguinte maneira: se as coisas, em sentido plural, são múltiplas, então essas

\footnotetext{
${ }^{23}$ Há duas cacofonias que tornam a assertiva pesada: "Que então é preciso (...), mas que...": "Quentão" e "masque"!

${ }^{24}$ eòn é a forma positiva do nominativo-vocativo-acusativo neutro singular do particípio presente do verbo ser/estar: sendo/estando.
} 
mesmas coisas, em sentido singular, devem, a um só tempo, ou seja, simultaneamente, ser semelhantes e dissemelhantes, o que é impossível. É impossível em razão de que o ser semelhante e o ser dissemelhante, do ponto de vista de Zenão, se excluem, de modo que o que é semelhante, enquanto é semelhante, não pode ser dissemelhante, nem o dissemelhante semelhante. As coisas, singularmente consideradas, não podem, a um só tempo, ser de tal modo e não-ser de tal modo: ser assim ou não-ser assim, ser e não-ser. Daí, portanto, o pressuposto de Parmênides: se algo é, então podemos percebê-lo com os sentidos, e, se o percebemos podemos pensá-lo, ou seja, exercitar sobre ele o logos humano com o qual conjugamos o pensar e o dizer, a intelecção e a nomeação; e mais: se algo não é, então, e evidentemente, não podemos sensitivamente percebê-lo, de modo que não se submete ao pensamento e "tampouco à palavra - oúte phrasais" ${ }^{25}$, restando, enfim, imperscrutável, ou seja, impensável e inominável, e, enfim, incognoscível;

$7^{\mathfrak{a}}$ ) Resultam, entretanto, duas coisas necessárias de serem evidenciadas e que implicam numa terceira: uma, a que diz respeito ao atributo da semelhança pressuposto como um princípio de identidade que predica o ser por sobre o aparecer; outra, a que diz respeito ao atributo da dissemelhança tomado como contraposto da semelhança e que, enfim, põe intelectivamente em evidência um princípio de diferença, de não-similitude, que predica o não-ser; daí uma terceira, a de que o pressuposto como idêntico, no contraposto do não-idêntico, leva necessariamente a uma constatação (empírica e intelectivamente considerada) segundo a qual o ser assim relativo ao não-ser assim é dada ao escrutínio do intelecto nos seguintes termos: do ser assim como ser de um certo modo, e, do não-ser assim, como um não-ser, mas não em sentido absoluto, e sim, em termos positivos, não mais negativo) como um ser de um outro modo.

A título de explanação tomemos o seguinte exemplo: o Sócrates guerreiro e o Sócrates filósofo são e não-são, a rigor, o mesmo Sócrates. Dá-se que o Sócrates enquanto guerreiro, ou seja, guerreando, é e não-é o mesmo Sócrates enquanto filósofo, ou seja, filosofando. Nesse caso, a semelhança e a dissemelhança se dão nos seguintes termos: o Sócrates guerreando participa da semelhança do Sócrates filosofando ou vice-versa. Entretanto, são dois Sócrates diferentes, que (isto na medida em que, por força da dissemelhança do estar sendo assim e não de outro modo) resultam em ser assim (no sentido de ser de tal modo) e em não-ser assim (no não-ser de tal modo) relativo a Sócrates. O próprio Sócrates, enfim, que é em si mesmo um, aparenta em si mesmo múltiplo. Donde resulta que o semelhante não pode ser dissemelhante e o dissemelhante semelhante, mas sob a seguinte advertência (aliás, aquela que foi feita por Sócrates ao argumento de Zenão), qual seja, a de que o semelhante não pode ser dissemelhante enquanto é semelhante, porque esse mesmo semelhante enquanto é dissemelhante relativo ao ser semelhante é dissemelhante.

Aliás, quando dizemos, por exemplo, João é semelhante a Pedro, por esse dizer afirmamos que João é, de certo modo, dissemelhante a si mesmo na medida em que é semelhante a Pedro, que, por sua vez, é, de certo modo, dissemelhante a si mesmo. Temos aqui, em um só ser (como já referido), o ser semelhante enquanto princípio de identidade e o ser dissemelhante, enquanto princípio de diferença; temos igualmente (também como já referido) o não-ser assim como um ser de outro modo. Em conclusão: dizer que as coisas ou seres não podem ser semelhantes e dissemelhantes resulta no mesmo que afirmar que não existem o uno e o múltiplo. A esse respeito não deixa de ser uma ironia de Sócrates, sobreposta ao argumento de Zenão, a consideração feita por ele, ainda no introito, a respeito do conjunto dos argumentos dos quais Zenão se valeu para demonstrar que o múltiplo não existe. Pergunta Sócrates: "Não estás convencido de que cada um dos teus argumentos

${ }^{25}$ DIELS \& KRANZ, Die Fragmente der Vorsokratiker, 28 B 2, 7-8. 
demonstra isso mesmo, e que, no teu modo de pensar, os argumentos por ti apresentados são outras tantas provas de que o múltiplo não existe?" (Prm. 127e - 128a, tradução de Carlos Alberto Nunes). Moral do dilema: “cada um dos argumentos - hécaston tôn lógonn" - de Zenão formam um múltiplo de argumentos com os quais ele quer provar, enfim, que o múltiplo não existe.

Por fim, parafraseando aqui Aristóteles [naquele adagio, que se tornou clássico, segundo o qual "uma só andorinha não faz verão, tampouco um dia de sol" (Ética a Nicômaco I, 7, 1098 a 16)], parece muito acertado dizer que um só argumento não faz a ciência, visto que, por "sua natureza", ela não é monológica. Foi, aliás, por sobre o conceito da dialogia e não da monologia, dentro de uma mentalidade dual pitagórica, que Platão concebeu a tarefa da Filosofia e da Ciência. Ele persegue, em última instância, o ideal heraclitiano segundo o qual as semelhanças geram concórdia, as diferenças, discórdia, ou a guerra, ou tantas coisas mais: a começar pela intolerância e pelo preconceito, seguida pela reprovação recíproca perante o não-igual, e, com ela, o império intransponível da discórdia, da antipatia, do desprezo, da discriminação e da segregação. Só a lei, amparada sob princípios de bondade e de justiça, harmoniza as diferenças, humaniza e dá cidadania, caso contrário, o diferente resta excluído, destituído de valores e de direitos.

Pode aparentar estranho, mas esta é a lógica, que, enfim, a partir do "tudo é um", imperou na mentalidade filosófica grega: nós (humanos) somos semelhantes porque somos dissemelhantes, e vice-versa, somos dissemelhantes, porque somos semelhantes. Se fôssemos todos apenas semelhantes então seríamos todos iguais, a ponto de entre nós, quer de um ponto de vista sensível quer inteligível, haver apenas uma única identidade de forma ou gênero humano, resultando que, antes de um múltiplo humano, comporíamos apenas um todo único, monolítico, destituído de diferenças ou de uma "pluralidade de formas" (Sph. 220a; 221e). Se, ao contrário, fossemos todos apenas dissemelhantes então seríamos todos totalmente desiguais ou diferentes, a ponto de entre nós, quer do ponto de vista do sensível quer do inteligível, ser totalmente impossível constituir um análogon relativo a uma identidade inferida nas semelhanças, resultando, enfim, que, sem semelhanças, comporíamos uma multiplicidade de entidades solitárias, isoladas e incognoscíveis, sem qualquer possibilidade de se conceber (existir), entre elas, uma unidade.

Foi assim, de um ponto de vista epistêmico, que findou em Aristóteles a convicção segundo a qual a ciência se faz por amostra: a partir de um número " $x$ " de coisas ou de fenômenos observados, exprime-se, por analogia dos casos semelhantes, um juízo universal $^{26}$. De um ponto de vista "político" a questão remonta a Heráclito, segundo o qual as semelhanças unem enquanto que as dissemelhanças promovem a discórdia e a guerra ${ }^{27}$. Daí a necessidade da lei no que diz respeito, sobretudo, às dissemelhanças. Dá-se que as semelhanças, na medida em que espontaneamente unem, em que promovem (como diz

\footnotetext{
${ }^{26}$ Os termos da dita dedução aristotélica, para além de Platão, remete a Filolau, aos seguintes fragmentos: a) "todo ser cognoscível (gignôskómena) tem um número, sem o qual nada poderíamos pensar ou conhecer (noêthêmen oúte ênôsthêmen)" (DIELS \& KRANZ, Die Fragmente der Vorsokratiker, 44 B 4); b) "nenhuma das coisas [existentes] a ninguém seria evidente (autôn poth’autá, no sentido de por si mesma manifesta), nem nela mesma e nem na sua relação com outra coisa, se não existisse o número e a essência (ousía) do número" (Idem, 44 B 11, 16-18 - os colchetes e parênteses foram acrescentados). Arquitas de Taranto (no livro Sobre as ciências - Peri mathêmáthôn) dizia que "o raciocínio (logismós), quando encontrado, faz cessar a discórdia e aumenta a concórdia, e, ao invés da superioridade (da pleonexía), reina a igualdade; é ainda por ele que nos colocamos de acordo com os que estamos em relações" (Idem, 47 B 3,7-10).

${ }^{27}$ Aristóteles, na Ética a Eudemos, teceu, a respeito de Heráclito, a seguinte consideração: "Heráclito censura o poeta por ter dito: Cesse a discórdia entre os deuses e os homens. Porque (segundo diz Heráclito) não poderia haver harmonia na música se não houvesse sons graves e agudos, assim como não poderia haver animais sem o macho e a fêmea, que são contrários" (Ét. a Eud. VII, I, 1235 a 25).
} 
Empédocles) o amor, então, por si só dispensam a severidade "unificadora" da lei, enquanto que as dissemelhanças, que tendem a separar e a segregar, isto é, a promover o ódio, a requisitam.

Em ambos os casos, enfim, quer de um ponto de vista epistêmico quer político é do pluralismo e não do monismo que imerge o um enquanto possibilidade da condição necessária quer do conhecimento ou ciência quer da harmonia ou do ordenamento da vida cívica. Visto que a justiça nasce da discórdia e que se realiza na concórdia, ou, dito de outro modo: visto que a justiça tem sua origem no conflito e seu fim na harmonia ou na paz, finda, então, que quanto maior, na vida cívica, a abrangência do múltiplo, maior igualmente a possibilidade do que hoje denominamos de Democracia. Dá-se que, assim como "os semelhantes (no dizer de Empédocles) nutrem os semelhantes" ${ }^{28}$, do mesmo modo os dissemelhantes, à medida que os semelhantes entre si se nutrem, ficam segregados ao desamparo caso não se promova, em nome do que é bom, belo e justo, a lei enquanto princípio universal de contenção, mas também, e, sobretudo, de união, de amor e de sabedoria entre os homens.

\section{Referências}

ALLEN, R. E. Plato. Parmenides. Minneapolis: University of Minnesota Press, 1983.

BAILLY, A. Dictionnaire Grec Français. Édition revue par L. Séchan et P. Chantraine. Paris: Hachette, 1996.

BARNES, J. Aristotle. The Complete Works of Aristotle. The Revised Oxford Translation, Princeton: Princeton University Press, 1984.

BURNET, J. Plato. Platonis Opera. 5 vols. T.I tetralogias I-II continens [insunt Euthyphro, Apologia, Crito, Phaedo, Cratylus, Theaetetus, Sophista, Politicus], recognoverunt brevique adnotatione critica instruxerunt W.A. Duke, W.F. Hicken, W.S.M. Nicoll, D.B. Robinson et J.C.G. Strachan. Oxford: Clarendon Press, 1995.

BOLZANI FILHO, R. “Glauco, o guardião do lógos”. Revista Dois Pontos, São Carlos/Curitiba, v. 10, n. 2, 2013, pp.11-32;

CLEMENE DE ALEXANDRIA. Les Stromates. Introduction par Claude Mondésert, traduction et notes de Marcel Caster. Paris: CERF, 2006.

CROMBIE, I. An Examination of Plato's Doctrines. Vol. II: Plato on Knowledge and Reality. London: Routledge, 1963.

DIELS, H. \& KRANZ, W. Die Fragmente der Vorsokratiker. 18ª ed., Zürich-Hildesheim: Weidmann, 1989.

DÜRING, I. Aristotele. Traduzione di Pierluigi Donini. Milano: Mursia, 1966.

IGLÉSIAS, M. \& RODRIGUES. F. Platão. Parmênides. Rio de Janeiro/São Paulo: PUC/Loyola, 2003.

LIDDELL, H. G., SCOTT, R. \& JONES, H. S. (1990). A greek-english lexicon. Revised Edition by H. Stuart-Jones. Oxford: Clarendon Press, 1968.

MOTTA, G. D. "Gláucon, Adimanto e a necessidade da filosofia”, Revista Kléos, n. 9/10, 2005/6, pp. 87-113;

${ }^{28}$ DIELS \& KRANZ, Die Fragmente der Vorsokratiker, 31 B 90. 
NIETZSCHE, F. A Filosofia na Idade Trágica dos Gregos. Trad. Maria Inês Madeira de Andrade. Lisboa: Edições 70, 1987.

NUNES. C. A.. Platão. Parmênides. Belém: Universidade Federal do Pará, 1974.

NUNES, C. A. Platão. Diálogos. Cartas. Belém: Universidade Federal do Pará, 1975.

PAUSÂNIAS. Descripción de Grecia. Trad. María Cruz Herrero Ingelmo. Madrid: Gredos, 1994.

PLOCLO. Commentaire sur le 'Parménide' de Platon. Traduction de Guilhaume de Moerbeke. 2 vols., Édition Critique par Carlos STEEL. Lieden: Brill, 1981.

PLUTARCO. Vidas Paralelas. Vol. I: Teseo-Rómulo, Licurgo-Numa; Trad. Aurelio Pérez Jiménes, Madrid: Gredos, 1985.

PlUtARCO. Vies. Périclè-Fabius Maximus. Alcibiade-Coriolan. Tome III. Texte établi et traduit par Robert Flacelière, Émile Chambry et Marcel Juneaux. Paris: Les Belles Lettres, 2012.

REALE, G. Diogene Laerzio. Vite e dottrine dei più celebri filosofi. Testo greco a fronte, con la collaborazione di Giuseppe Girgenti e Ilaria Ramelli. Milano: Bompiani, 2005.

SPINELLI, M. Ética e Política: a edificação do éthos cívico da paideia grega. São Paulo: Loyola, 2017.

SPINELLI, M. Questões Fundamentais da Filosofia Grega, São Paulo: Loyola, 2006.

SPINELLI, M. Herança Grega dos Filósofos Medievais. São Paulo: Hucitec, 2013.

TUÑÓN, O. G. Xenofonte. Helénicas. Introducción, traducción y notas. Asesor para la sessión griega Carlos García Gual. Madrid: Gredos, 1994.

TUCÍDIDES. História da Guerra do Peloponeso. Trad. João José Torres Esbarranch. Madrid: Gredos, 1990.

VOILQUIN, J. Aristotele. Éthique à Nicomaque, texte établi et traduit. Paris: Garnier, 1961.

YEBRA, V.G. Aristoteles. Metafísica. Edição trilingüe. Madrid: Gredos, 1982. 